\title{
The effect of a direct fed microbial (Megasphaera elsdenii) on the productivity and health of Holstein cows
}

\author{
F.M. Hagg ${ }^{1,2 \#}$, L.J. Erasmus ${ }^{2}$, P.H. Henning ${ }^{1}$ and R.J. Coertze ${ }^{2}$ \\ ${ }^{1}$ MS Biotech, PO Box 10520, Centurion 0046, South Africa \\ ${ }^{2}$ Department of Animal and Wildlife Sciences, Faculty of Natural and Agricultural Sciences, University of Pretoria, \\ Pretoria 0002, South Africa
}

\begin{abstract}
Sixty high-producing multiparous Holstein cows were used in a randomized complete block design experiment to determine the effect of a direct-fed microbial (DFM), Megasphaera elsdenii NCIMB 41125 $(M e)$, on dairy cattle productivity and health. The cows received one of two experimental diets (total mixed rations (TMR)) from calving until 60 days post partum. Two experimental diets were formulated, namely a low concentrate diet (40\% roughage : $60 \%$ concentrate) and a high concentrate diet $(30 \%$ roughage : $70 \%$ concentrate) that were fed as a TMR for the duration of the trial. The low and high concentrate diets contained respectively $181 \mathrm{~g} / \mathrm{kg}$ and $178 \mathrm{~g} / \mathrm{kg}$ of crude protein, $448 \mathrm{~g} / \mathrm{kg}$ and $504 \mathrm{~g} / \mathrm{kg}$ of non-fibre carbohydrate, $282 \mathrm{~g} / \mathrm{kg}$ and $238 \mathrm{~g} / \mathrm{kg}$ of neutral detergent fibre and $42 \mathrm{~g} / \mathrm{kg}$ and $43 \mathrm{~g} / \mathrm{kg}$ of ether extract. There were four experimental treatments, namely: (1) Low concentrate diet control (LCC), (2) Low concentrate diet and dosed with Me (LCD), (3) High concentrate diet control (HCC) and (4) High concentrate diet and dosed with $M e$ (HCD). Dosing with Me did not show any advantage, regardless of level of concentrate. Dry matter intake, milk production, milk composition, feed efficiency, body mass and body condition score were not affected by treatment. Furthermore, treatment did not affect rumen $\mathrm{pH}$, rumen lactic acid or volatile fatty acid concentrations. Faecal $\mathrm{pH}$, however, was statistically significantly higher, and faecal starch content significantly lower in cows dosed with $M e$. Lack of results suggests that further research is needed on dose time and/or frequency as well as the option to use it as an infeed product.
\end{abstract}

Keywords: Rumen acidosis, dairy cows, rumen fermentation, milk yield, health.

${ }^{\#}$ Corresponding author. E-mail: frans@msbiotech.biz

\section{Introduction}

Modern day intensive production systems, especially with high producing dairy cows, involve the feeding of high levels of concentrates in order to supply sufficient nutrients to support a high level of milk production. Feeding these high levels of concentrate often leads to metabolic dysfunction and eventually rumen acidosis; especially under conditions of poor methods of feeding and/or composition of diets. Ruminal acidosis can be defined as an array of biochemical and physiological stresses caused by rapid production and absorption of ruminal organic acids (Britton \& Stock, 1987). The goal of the nutritionist, when implementing high concentrate feeding programmes is to maximize performance and efficiency, while keeping digestive disturbances such as rumen acidosis within acceptable limits through good nutritional management (Henning, 2004). If rumen acidosis is not controlled, it could lead to problems such as irregular feed intake, reduced milk production, digestive disturbances, possible reproduction and health problems such as laminitis, lung diseases and endometritis (Hall, 1999).

Theoretically a number of approaches can be followed to control the incidence of rumen acidosis. One approach is to inhibit the growth of lactic acid producing bacteria such as Streptococcus bovis and Lactobacillus species through the use of feed supplements such as ionophores (Callaway \& Martin, 1997). Another approach is to use direct-fed microbials (DFM) such as Megasphaera elsdenii, a lactic acid utilizer, to regulate lactic acid levels in the rumen through increasing the population of lactic acid utilising bacteria (Robinson et al., 1992).

Kung et al. (1995) reported in vitro results on M. elsdenii and observed that M. elsdenii prevented high levels of lactate accumulation in the rumen, but the magnitude of the effect depended on the initial dosing rate. These researchers also observed that concentrations of acetate and propionate were lower and concentrations of isobutyrate, butyrate, isovalerate, and valerate higher when M. elsdenii was added 
compared to the control. Robinson et al. (1992) dosed steers intra-ruminally with M. elsdenii. These researchers reported reductions in lactate accumulation, higher ruminal $\mathrm{pH}$, and a $24 \%$ increase in dry matter intake (DMI) above that of the control animals. Hibbert et al. (1993) reported that drenching with M. elsdenii improved feed intake and prevented rumen acidosis in beef cattle when changing from a 50 to a $90 \%$ concentrate diet. Erasmus (1997) conducted a study, similar in design to the present study, except that he also divided the cows into low and high producers. He observed an increase in milk production for a high producing group of cows when Megasphaera elsdenii NCIMB 41125 (Me) was dosed compared to the control animals. An increase in milk production was observed for high producing second lactation cows in a field trial conducted by KK Animal Nutrition (Hagg \& Henning, 2007) where Me were dosed after calving. Aikman et al. (2008) observed an increase in milk production and feed intake for the first 21 days of lactation when $M e$ were dosed compared to the control animals. Therefore, if Me could be used successfully to assist in the prevention of lactic acid accumulation in the rumen, it could benefit the dairy industry in two major ways. Firstly it will decrease the number of early lactation cows experiencing rumen acidosis, thereby improving the health, number of lactations and production of the cows. Secondly, because Me is a microorganism that occurs naturally in the rumen, it can be used as a natural treatment which is more favourable to use compared to the use of antibiotics, as a tolerance against antibiotics is becoming a serious problem in the industry. Additional research is clearly needed to properly evaluate the effectiveness of $M e$ in the feeding programme of the early post-partum cow.

The objective of this study was to determine the effect of dosage of live $M e$, a natural lactate utilising bacteria, on the productivity and health of early lactation Holstein cows.

\section{Material and Methods}

Sixty multiparous Holstein-Friesian dairy cows, mean body weight (BW) $625 \pm 40.7 \mathrm{~kg}$ and a body condition score of $2.59 \pm 0.205$, were used in a randomized complete block design experiment. Three weeks pre-partum, cows were assigned to one of 15 blocks of four cows, based upon parity and previous lactation milk production. The dairy cows were divided randomly into four groups, namely, (1) low concentrate diet, control (LCC), (2) low concentrate diet, dosed with $\mathrm{Me}$ (LCD), (3) high concentrate diet, control (HCC) and (4) high concentrate diet, dosed with $M e$ (HCD).

During the period from 21 days pre-partum until calving the cows received $7 \mathrm{~kg}$ total mixed ration (TMR) (low concentrate diet) supplemented with $400 \mathrm{~g}$ anionic salts per day. The anionic salts consisted of a mixture of $200 \mathrm{~g} \mathrm{NH}_{4} \mathrm{Cl}_{2}$ and $200 \mathrm{~g} \mathrm{MgSO}_{4}$. Medium quality Eragrostis curvula hay $(140 \mathrm{~g} \mathrm{CP} / \mathrm{kg} ; 630 \mathrm{~g}$ $\mathrm{NDF} / \mathrm{kg}$ and $900 \mathrm{~g} \mathrm{DM} / \mathrm{kg}$ ) was available ad libitum. After calving cows were moved to a semi-intensive housing unit equipped with Calan head-gates (American Calan Inc., Northwood, NH, USA) for individual feeding. Cows had access to a dirt exercise area of $200 \mathrm{~m}^{2}$. During the 60 days post-partum experimental period the cows only received their allocated TMR's without any additional hay. Cows entered the trial at calving and due to restricted numbers of cows available the cows enter the trial over a period of 11 month.

The TMR was fed ad libitum once a day after the morning milking. Feed allocations were monitored daily to ensure $5-10 \%$ refusals. Thirty percent water was mixed into the TMR to decrease dustiness and feed selection, and to enhance feed intake. Dry matter intake variation was calculated by subtracting the previous day's DMI from the present day's DMI. An average was then calculated using the differences. The experimental diets were formulated using the CPM-Dairy programme (version 3.0.5, 2006). Fresh water was available ad libitum.

The trial was conducted at the University of Pretoria Experimental farm, Pretoria, SA. It's an area with summer rainfall. Animals were cared for according to the guidelines for The Care and Use of Animals in Agriculture, Research and Teaching (1999) and animal use was approved by the Animal Use and Care Committee of the University of Pretoria, approval number EC041015-030.

The cows were milked three times per day: at 05:00, 12:00 and 19:00 respectively, in a 10-point herringbone DeLaval milking parlour (DeLaval (Pty. Ltd), Pinetown, 3600, South Africa).

Throughout the trial period cows were monitored for any health problems and treated accordingly. When any positively diagnosed health problem affected a reduction in DMI and/or milk production of 30\% or more of the previous week's production or DMI for more than five days, the cow was culled from the trial and replaced with a healthy cow applicable to that production block. The replacement cow started the trial after calving, thus for the 60 day trial period. The reasoning for the replacement of cows is that we wanted to 
determine the effect of Me dosing on the production of healthy cows. Records were kept of all diagnosed health problems, as well as the numbers of all the cows that were culled from the trial.

Table 1 Ingredient and nutrient composition of the experimental diets fed both pre-partum and post-partum (DM) for early lactation Holstein cows

\begin{tabular}{lcc}
\hline Composition & Low concentrate & High concentrate \\
\hline Ingredient \% & 31.9 & \\
Lucerne hay & 7.9 & 19.6 \\
Eragrostis curvula hay & 35.4 & 7.9 \\
Maize meal (ground) & 3.9 & 47.9 \\
Molasses & 7.9 & 3.9 \\
Whole cottonseed & 10.2 & 7.5 \\
Soyabean meal & 1.6 & 9.4 \\
Maize gluten 60 & - & 2 \\
Urea & 0.79 & 0.27 \\
Di-calcium phosphate & 0.39 & 0.79 \\
Mineral/vitamin premix ${ }^{1}$ & & 0.39
\end{tabular}

Nutrient composition

Dry matter, $\mathrm{g} / \mathrm{kg}$

Roughage, $\mathrm{g} / \mathrm{kg}$

Crude protein, $\mathrm{g} / \mathrm{kg}$

Soluble crude protein, $(\% \mathrm{CP})$

ME, $(\mathrm{MJ} / \mathrm{kg} \mathrm{DM})^{2}$

NFC, $g / k g$

$\mathrm{NDF} g / \mathrm{kg}$

pe NDF $\mathrm{g} / \mathrm{kg}$

Ether Extract g/kg

Calcium $\mathrm{g} / \mathrm{kg}$

\footnotetext{
${ }^{1}$ Contains per kg premix: $7000 \mathrm{IU}$ vitamin $\mathrm{A} ; 1500 \mathrm{IU}$ vitamin $\mathrm{D}_{3} ; 1300 \mathrm{mg}$ vitamin $\mathrm{B}_{1} ; 4000 \mathrm{mg}$ vitamin $\mathrm{B}_{12}$; $15000 \mathrm{mg}$ vitamin E; $130000 \mathrm{mg}$ niacin; $1000 \mathrm{mg} \mathrm{Co}, 3000 \mathrm{mg} \mathrm{I} ; 375 \mathrm{mg} \mathrm{Se} ; 100000 \mathrm{mg} \mathrm{Mn} ; 20000 \mathrm{mg} \mathrm{Cu}$; $100000 \mathrm{mg} \mathrm{Zn;} 350000 \mathrm{mg} \mathrm{S} ; 60000 \mathrm{mg} \mathrm{Fe}$.

${ }^{2}$ Calculated using the database of Van der Merwe \& Smith (1991);

UDP - undegradable dietary protein;

$\mathrm{NFC}$ - non fibre carbohydrate $=100-(\mathrm{CP}+\mathrm{EE}+\mathrm{Ash}+\mathrm{NDF})$;

NDF - neutral-detergent fibre;

pe NDF ${ }^{-}$physical effective neutral-detergent fibre.
}

The amount of TMR offered and refused was recorded daily. Samples of TMR's were collected every 14 days, frozen at $-20{ }^{\circ} \mathrm{C}$ and composited by treatment on a monthly basis. Refusals were sampled every 14 
days, frozen at $-20{ }^{\circ} \mathrm{C}$ and composited within cow. Samples of TMR and refusals were dried at $60{ }^{\circ} \mathrm{C}$ for 24 hours for DM analysis. The following analyses were performed on the feed samples: DM (AOAC, 2000, method 934.01, CP (AOAC, 2000, method 988.05), EE (AOAC, 2000, method 920.39), ash (AOAC, 2000, method 942.05), P (AOAC, 2000, method 965.17 and soluble CP (AOAC, 2000, method 988.05), NDF (Van Soest \& Roberston, 1981) and ADF (Goering \& Soest, 1988), as well as Ca (Castellano Giron, 1973). Non-fibre carbohydrate was calculated from assayed nutrients (NRC, 2001). Refusals were analysed for NDF and CP only.

Milk production was measured on a daily basis for 60 days after calving and 305 day milk production predictions were calculated by personnel from the National Dairy Animal Improvement Scheme (Iris programme version 33,2006 ). Milk samples were taken once a week during the 12:00 milking. The milk samples were analysed for milk fat, milk protein, milk urea nitrogen (MUN) and milk lactose, using the System 4000 Infrared Analyzer (Foss Electric, Hillerod, Denmark).

Rumen fluid samples were taken on days 15 and 30 post-partum between four and five hours after the morning feeding, using the Rumenocentesis procedure described by Nordlund \& Garrett (1994). Because the trial was designed as a production trial and only non-cannulated cows were used in the trial, it was not possible to collect rumen samples on a frequent basis. Therefore the results of the analyses of the rumen samples were only used as an indication to what has happened in the rumen. The $\mathrm{pH}$ of the rumen fluid sample was measured within 30 seconds after sampling, using a portable $\mathrm{pH}$ meter (IQ Scientific palm $\mathrm{pH} / \mathrm{mV} /$ Thermometer, PM Instrumentation, Norwood, Johannesburg). The rumen fluid samples were then filtered through two layers of cheesecloth. One $\mathrm{mL}$ of the filtered rumen fluid was stored at $-10^{\circ} \mathrm{C}$ for lactic acid analysis using a modification of the Barker-Summerson method (Pryce, 1969). Another $4 \mathrm{~mL}$ of the filtered rumen fluid was preserved with $1 \mathrm{~mL}$ of $25 \% \mathrm{H}_{3} \mathrm{PO}_{4}$ (orthophosphoric acid) and then stored at $-10{ }^{\circ} \mathrm{C}$ for volatile fatty acid (VFA) analysis using a gas chromatographic method (Gibbs et al., 1973).

Rectal faecal samples were taken from all cows on days 15 and 30 post partum, at the same time as the rumen samples. Faecal $\mathrm{pH}$ was measured with a portable $\mathrm{pH}$-meter (IQ Scientific Palm $\mathrm{pH} / \mathrm{mV} /$ Thermometer). After the faecal sample was taken the cow was further stimulated rectally by hand to encourage the excretion of more faeces that dropped to the ground. A faecal score was determined and the amount of gas bubbles in the faeces was observed. The faecal samples were stored at $-10{ }^{\circ} \mathrm{C}$ immediately after collection for later starch analysis (MacRae et al., 1968).

Cows were weighed and body condition scored at assignment and thereafter every second week. The five point BCS system ( 1 = severe under condition, 5 = severe over condition) was used (Wildman et al., 1982).

Me was dosed to the allocated group of cows at 13:00 on days 2,10 and 20 post-partum. Each dosing contained $250 \mathrm{~mL}$ of live $10^{9}$ colony forming units (cfu) $M e / \mathrm{mL}$. The dosing size and number of cfu Me was determined by Apajalathi et al. (2008) where they increase the cfu of $M e$ from $8 \times 10^{5}$ to $2 \times 10^{8}$ and decrease the lactic acid levels from $21 \mathrm{mmol}$ to $8 \mathrm{mmol}$ in an in vitro system where the same ratio of $M e$ cfu to rumen digesta volume compares to $250 \mathrm{~mL}$ of live $10^{9} \mathrm{cfu} \mathrm{Me} / \mathrm{mL}$ dosed to a Holstein dairy cow. The Me was prepared 24 hours prior to dosing by inoculating fresh growth medium $(200 \mathrm{~mL})$ with $\mathrm{Me}$ culture $(50 \mathrm{~mL})$ and then incubated in a thermostatically controlled water bath incubator (HETO Lab. Equipment, Denmark) for 24 hours at $39{ }^{\circ} \mathrm{C}$. The resulting culture was then drawn up into a $300 \mathrm{~mL}$ dosing syringe and the cow dosed. The Me were produced at the Gastro Intestinal Microbiology and Biotechnology Laboratory of the Livestock Business Division, ARC, Irene, South Africa. Although the rumen samples were not analysed for $M e$ to determine if $M e$ did colonise in the rumen, it was proved by other studies that $M e$ does colonise in the rumen if a significant amount of starch was fed to the animal (Aikman et al., 2008)

Data were analyzed as a randomized complete block design with the GLM model (SAS, 2001) for the average effects over time. Repeated measures analysis of variance with the GLM model was used for repeated week or perennial measures. Means and standard error of the means (s.e.m.) were calculated and significance of difference between means was determined by the Fishers test (Samuels, 1989). Significance was declared at $\mathrm{P}<0.05$ unless otherwise noted.

\section{Results and Discussion}

Diets were formulated to slightly exceed the requirements for metabolizable energy (ME) and microbial protein (MP) for a $605 \mathrm{~kg}, 37$ month old cow at 50 DIM producing $45 \mathrm{~kg}$ of $3.9 \%$ fat, 3.3\% milk protein/day (CPM, 2006, Version 3.0.5) and consuming $24 \mathrm{~kg}$ of DM/day. Chemical analysis of refusals 
indicated that no selective feeding occurred and that the chemical composition of the diets that were consumed differed little from the mean chemical composition of the formulated diets (data not shown).

Results on DMI, milk production and feed efficiency are presented in Table 2. The average DMI was $23.3 \mathrm{~kg} / \mathrm{d}$ which is $3.7 \%$ of average BW and is considered normal for this stage of lactation (NRC, 2001). There was no difference $(\mathrm{P}>0.05)$ in the average DMI between the different treatments. There was, however, as expected, a difference $(\mathrm{P}<0.05)$ in DMI between the high and low concentrate diets. The cows receiving high concentrate diet consumed on average $24.0 \mathrm{~kg}$ DM per day whereas the cows receiving the low concentrate diet consumed $22.7 \mathrm{~kg}$ DM per day.

Erasmus (1997) observed an average DMI of 22.2 to $24.6 \mathrm{~kg}$ /day and Mutsvangwa et al. (2002) reported a DMI of 22.1 to $23.0 \mathrm{~kg}$ /day in early lactating Holstein cows on lucerne based TMR's which is in agreement with results from this study. Aikman et al. (2008) conducted a trial to determine the effect of Me on the productivity of early lactation Holstein cows with two TMR's differing in level of concentrate. They observed no difference in DMI $(20.0-21.0 \mathrm{~kg}$ DMI $)$ between the control and treated groups during the first 14 weeks of lactation.

A characteristic of cows that experience rumen acidosis is a diurnal variable intake (Nocek, 1997). There was no difference $(\mathrm{P}>0.05)$ in DMI variation between the different treatment groups. There was, however, a tendency towards a higher variation in DMI $(\mathrm{P}=0.08)$ in the high concentrate diet group.

Table 2 The effect of dosing live Megasphaera elsdenii NCIMB 41125 on dry matter intake (DMI), milk production, body condition score, milk composition and feed efficiency of high producing, early lactation, Holstein cows

\begin{tabular}{|c|c|c|c|c|c|c|c|c|}
\hline & \multicolumn{6}{|c|}{ Treatments } & \multicolumn{2}{|c|}{ Main Effects } \\
\hline & LCC & LCD & $\mathrm{HCC}$ & $\mathrm{HCD}$ & s.e.m. & $\mathrm{P}=$ & $\begin{array}{c}\text { Control / } \\
\text { Dosed } \\
\mathrm{P}=\end{array}$ & $\begin{array}{c}\text { Low / High } \\
\text { conc. } \\
\mathrm{P}=\end{array}$ \\
\hline DMI (kg/day) & $23.1^{\mathrm{ab}}$ & $22.4^{\mathrm{a}}$ & $24.3^{\mathrm{b}}$ & $23.8^{\mathrm{ab}}$ & 0.64 & 0.83 & 0.36 & 0.05 \\
\hline DMI variation $(\mathrm{kg} / \mathrm{day})^{1}$ & 2.88 & 2.69 & 3.06 & 3.12 & 0.17 & 0.47 & 0.71 & 0.08 \\
\hline $\begin{array}{l}\text { Average daily milk production }(\mathrm{kg} \\
\mathrm{milk} / \mathrm{d})\end{array}$ & 43.9 & 42.7 & 45.1 & 44.2 & 1.53 & 0.91 & 0.51 & 0.39 \\
\hline Predicted 305-d production $(\mathrm{kg})^{2}$ & 12052 & 11697 & 11929 & 11438 & 329.0 & 0.84 & 0.21 & 0.57 \\
\hline \multicolumn{9}{|l|}{ Milk composition } \\
\hline Fat, \% & $3.34^{\mathrm{ab}}$ & $3.58^{\mathrm{a}}$ & $3.60^{\mathrm{a}}$ & $2.88^{\mathrm{b}}$ & 0.24 & 0.05 & 0.31 & 0.37 \\
\hline Protein, \% & $3.12^{\mathrm{ab}}$ & $3.01^{\mathrm{a}}$ & $3.12^{\mathrm{ab}}$ & $3.18^{\mathrm{b}}$ & 0.05 & 0.09 & 0.62 & 0.08 \\
\hline Lactose, $\%$ & 4.70 & 4.70 & 4.86 & 4.81 & 0.06 & 0.71 & 0.75 & 0.03 \\
\hline MUN (mg/dL) & $16.3^{\mathrm{a}}$ & $15.4^{\mathrm{ab}}$ & $13.6^{\mathrm{b}}$ & $14.9^{\mathrm{ab}}$ & 0.90 & 0.23 & 0.82 & 0.07 \\
\hline Body weight (kg) & 634 & 616 & 634 & 616 & 10.47 & 0.99 & 0.09 & 0.98 \\
\hline Body condition score $(1-5)$ & 2.55 & 2.61 & 2.59 & 2.59 & 0.15 & 0.77 & 0.76 & 0.89 \\
\hline Feed efficiency (kg milk/kg DMI) & 1.93 & 1.94 & 1.88 & 1.91 & 0.06 & 0.83 & 0.79 & 0.54 \\
\hline
\end{tabular}

${ }^{\mathrm{ab}}$ Means in the same row with different superscripts differ $(\mathrm{P}<0.05)$.

LCC - Low concentrate control; LCD - Low concentrate dosed; HCC - High concentrate control;

HCD - High concentrate dosed.

s.e.m. - standard error of the means.

${ }^{1}$ DMI Variation - Calculated by subtracting the previous day's DMI from the present day's DMI. An average was calculated using the differences.

2 305-day milk production prediction determined from the standard lactation curves, based on milk production levels, breed, age and calving season (Iris version 33 Intergis 2000 programme). 
One factor that probably contributed to the apparent lack of a significant incidence of rumen acidosis is that the cows were not able to feed selectively as was illustrated by the similar composition between orts and diet offered.

When the treated animals were compared to the control animals there was no difference $(\mathrm{P}>0.05)$ in milk production (Table 2) which was on average $44.0 \mathrm{~kg} / \mathrm{day}$. When the milk production of only the eight high producing cows (selected on previous lactation production) of each group was compared, there was a tendency $(\mathrm{P}=0.06)$ towards a higher milk production in the HCC and HCD groups compared to the LCC and LCD groups (data not shown). Aikman et al. (2008) did not observe a response in milk production when $M e$ - treated cows were compared to the control cow group, but observed an increase in milk production during the first 14 weeks of lactation when the milk production of the cows consuming the high concentrate diet was compared with the low concentrate diet group in their $2 \times 2$ factorial study with diet concentrate level and $M e$ as the two factors.

There was furthermore no difference $(\mathrm{P}>0.05)$ in total 305 -day predicted milk production. Similar full lactation results were reported by others when Holstein cows were fed lucerne maize based diets (Krause et al., 2002).

One can speculate on why milk production was not affected by Me dosing in this trial. Two factors might have contributed to the lack of response, namely the composition of the diet itself and secondly the overall management. Although the high maize content of the concentrate diet was $48 \%$ and the NDF level around $34 \%$, the maize could have been ground too coarsely and the diet did not lack effective fibre. The general management in terms of mixing feed uniformly, fibre length, no empty bunks etc. was excellent and it is possible that differences might be more pronounced under less than optimal management situations. Another possible reason for a lack of response is the frequency of Me dosing. It could be reasoned that if $M e$ would have been dosed to the cows on a more regular base, one could expect a possible increase in production.

Feed efficiency is generally expressed as $\mathrm{kg}$ milk/kg DMI and is increasingly being used as a troubleshooting tool and as one of the factors that impact on profitability of the enterprise (Linn, 2006). The feed efficiency varied from $1.88-1.94$ and did not differ between treatments $(\mathrm{P}>0.05)$ or between high and low concentrate diets $(\mathrm{P}=0.54)$. According to Hutjens (2002) cows during early lactation should have a feed efficiency of 1.8 or higher, which is in agreement with this study. Aikman et al. (2008) also reported an average feed efficiency of 1.83. Such high feed efficiencies support the suggestion that subacute ruminal acidosis (SARA) was probably not present at high enough levels so that Me could have elicited a response, but with lactic acid acidosis $M e$ could have an effect.

There was no effect $(\mathrm{P}>0.05)$ of $\mathrm{Me}$ dosing on milk composition when dosed vs. control treatments were compared (Table 2). There was, however, a difference $(\mathrm{P}<0.05)$ between the butterfat percentage when HCC (3.6\%) vs. HCD (2.9\%) were compared. The low fat \% for the HCD group cannot be explained, especially since the acetic : propionic acid ratios, NDF and NFC levels were similar for the HCD and HCC diets (Table 1). It should be noted, however, that a butterfat depression can be expected when the acetic: propionic acid ratio declines below 2.2 : 1 (Sutton et al., 2003). Similarly, Kennelly \& Khorasani (2001) could not offer any explanation why cows fed a 50\% concentrate diet produced milk with a significant lower fat content when compared to a diet containing 75\% concentrate. Aikman et al. (2008) observed no response in milk fat and milk protein content when $M e$ were dosed to cows consuming either a $60 \%$ concentrate diet or a $70 \%$ concentrate diet. Hagg \& Henning (2007) reported no difference in milk fat percentage when $\mathrm{Me}$-dosed cows were compared to control cows. Other researchers reported similar values for milk fat and protein of Holstein cows with similar levels of production (Krause et al., 2002).

The milk fat percentage was not affected by the dosing of Me and that was expected because there was no significant differences in the acetic acid : propionic acid ratio in the control vs. dosed groups. Others, however, have reported much lower milk fat percentage with diets resulting in similar acetic : propionic ratios (Kennelly et al., 1988). Comparing results should be done with caution, since it is well established that forage source and NDF concentration of forage significantly impact on milk fat percentage (Beauchemin et al., 1994).

Milk protein and milk lactose percentages were not influenced by dosage of Me (Table 2). The average milk protein varied between $3.01 \%$ and $3.18 \%$ which is acceptable for Holsteins producing on average $44 \mathrm{~kg}$ milk/day. Erasmus (1997) observed milk protein levels of $3.02-3.15 \%$ for cows producing on average 38 $\mathrm{kg} / \mathrm{d}$ on lucerne maize diets; this is in agreement with our results. The protein percentage of the milk can be 
affected by various factors such as starch fermentability, dietary CP percentage, RDP : UDP ratio, amino acid profile of UDP, as well as the amount of microbial protein synthesis (NRC, 2001). Rumen acidosis can affect milk protein since ruminal bacteria that degrade feed protein to amino acids and urea, as well as microorganisms that synthesize protein are negatively affected by a low $\mathrm{pH}$ in the rumen. The lack of any effect of $M e$ on milk protein supports the suggestion that the rumen environment and rumen fermentation were not affected to an extent that microbial protein production was significantly affected.

In general, milk lactose showed little variation, regardless of dietary composition and ranged between 4.5 and $4.8 \%$ (Tamminga, 2001). This is in agreement with values reported in this study.

There was no difference between the control and dosed cows when MUN concentrations were compared (Table 2). There was, however, a difference $(\mathrm{P}<0.05)$ between the MUN levels when LCC $(16.3$ $\mathrm{mg} / \mathrm{dL}$ vs. HCC $(13.6 \mathrm{mg} / \mathrm{dL})$ were compared. MUN levels were furthermore higher when the low concentrate diet groups were compared to the high concentrate diet groups $(\mathrm{P}=0.07)$. This could be due to the slightly higher CP level and lower energy level in the low concentrate diet compare to the high concentrate diet. It is well established that higher levels of fermentable carbohydrates lead to increased efficiency of rumen nitrogen utilisation for microbial crude protein resulting in lower MUN values (Broderick, 2003). Acceptable MUN values are between $10-16 \mathrm{mg} / \mathrm{dL}$ milk (Jonker et al., 1998). Erasmus et al. (2005) observed an average MUN of $12-15 \mathrm{mg} / \mathrm{d}$ in their trial with Holstein dairy cows where similar diets were fed. The differences observed in this study were within acceptable norms and the differences therefore not biologically important.

Mean body weight varied between $616 \mathrm{~kg}$ and $634 \mathrm{~kg}$ and did not differ between treatments $(\mathrm{P}=0.98)$ (Table 2). These values are in agreement with other early lactation studies with Holstein cows (Erasmus et al., 2005; Johnson-Van Wieringen et al., 2007). Body condition score is a helpful tool to evaluate the energy status of dairy cows. The ideal BCS at calving is 3.5 and cows should ideally not lose more than one BCS point ( $\pm 60 \mathrm{~kg}$ ) during the first 100 days (Gallo et al., 1996). The average BCS for the cows was 2.58 which is in agreement with recommendations. No treatment differences in body weight or BCS were expected in light of the fact that there were no treatment differences in either milk production or DMI.

The effect of Me dosing on rumen parameters such as $\mathrm{pH}$, VFA and lactic acid is shown in Table 3. Mean rumen $\mathrm{pH}$ (calculated using the $\mathrm{pH}$ of both rumen samples taken on days 15 and 30 post partum) was not affected by the dosing of $M e$ and the average rumen $\mathrm{pH}$ for the experimental treatments ranged from 5.74 to 5.92. These values are in agreement with results reported by Aikman et al. (2008) as well as Erasmus et al. (2005) where Holstein cows were fed a lucerne maize based diet where the average rumen $\mathrm{pH}$ was 5.79 during the first 60 days of lactation. Maekawa et al. (2002) reported an average rumen pH of 5.84 in Holsteins fed a $60 \%$ concentrate : $40 \%$ roughage TMR. Subacute ruminal acidosis (SARA) has been defined as a decrease in pH below 5.6 (Owens et al., 1998) or even below 5.8 (Krause \& Combs, 2003). The severity of SARA, however, is characterised by the time duration of ruminal pH below 5.6 or 5.8 (Keunen et al., 2002). In an in vitro trial that was conducted by Kung et al. (1995) it was reported that the rumen fluid pH of the culture that was treated with M. elsdenii declined from 6.6 to 5.5 within four hours of fermentation. The $\mathrm{pH}$ of the untreated rumen cultures declined from 6.6 to 4.8. This suggests that M. elsdenii has the potential to regulate $\mathrm{pH}$ and prevent a severe drop in $\mathrm{pH}$. In our study, however, average rumen $\mathrm{pH}$ was similar between dosed ( $\mathrm{pH} 5.83$ ) and control cows ( $\mathrm{pH}$ 5.82).

There was no significant effect of $M e$ on the VFA profile in the rumen (Table 3). However, there was a significant $(\mathrm{P}<0.05)$ increase in rumen propionic acid in the high concentrate diets compare to the low concentrate diets. This was expected since the high concentrate diet contained more starch and less fibre and the end-products of fermentation of these products are more propionic acid and less acetic acid (Sutton et al., 2003). Caution should be taken with the interpretation of the VFA results due to the small number of samples as this could not give a clear picture of what happened in the rumen, because the VFA composition in the rumen is very variable over time. Aikman et al. (2008) reported a tendency $(\mathrm{P}=07)$ towards lower acetate : propionate ratio in the Me-treated groups compared to the control groups. Kung et al. (1995) observed a decrease $(\mathrm{P}<0.05)$ in acetate and propionate when fermentation cultures were inoculated with Me. Kung et al. (1995) also found that the isobutyrate, butyrate and valeric acid concentrations increased (P $<0.05$ ). Others (Marounek et al., 1989; Slyter et al., 1992) have also reported an increase in butyrate production when $M$. elsdenii has been grown in a glucose-based growth culture.

Lactic acid concentrations were higher in the high concentrate diets compared to the low concentrate diets $(\mathrm{P}<0.01)$ primarily due to the higher starch content and lower fibre content of the high concentrate 
diets; dosing, however, did not affect lactic acid levels ( $\mathrm{P}>0.05)$. In contrast, Kung et al. (1995) found a reduction $(\mathrm{P}<0.05)$ in lactic acid ( $\mathrm{D}$ and $\mathrm{L}$ - lactate) after rumen fluid culture was treated with $M$. elsdenii, compared to the control culture. These authors suggested that $M$. elsdenii has potential to reduce the lactic acid concentration in the rumen and therefore assist in the prevention of rumen acidosis. The average lactic acid concentration in our study was $3.78 \mathrm{mg} / 100 \mathrm{~mL}$ which is in agreement with results from Oetzel et al. (1999). They collected rumen fluid from 154 cows in 14 different TMR fed herds and found the average lactic acid level to be $4.05 \mathrm{mg} / \mathrm{dL}$. However, recent research suggests that rumen acidosis observed in early and mid lactation cows is more related to total ruminal VFA production and VFA build-up in the rumen (De Vries et al., 2008). High rumen fluid lactic acid concentrations may not play as prominent a role in dairy "rumen acidosis" as it does in feedlot cattle (NRC, 2001)

Table 3 The effect of dosing live Megasphaera elsdenii NCIMB 41125 on rumen fluid pH, rumen fluid volatile fatty acid (VFA) and lactic acid concentrations of high producing, early lactation, Holstein cows

\begin{tabular}{|c|c|c|c|c|c|c|c|c|}
\hline & \multicolumn{6}{|c|}{ Treatments } & \multicolumn{2}{|c|}{ Main Effects } \\
\hline & $\mathrm{LCC}$ & LCD & $\mathrm{HCC}$ & $\mathrm{HCD}$ & s.e.m. & $\mathrm{P}=$ & $\begin{array}{c}\text { Control / } \\
\text { Dosed } \\
\mathrm{P}=\end{array}$ & $\begin{array}{c}\text { Low / } \\
\text { High conc. } \\
\mathrm{P}=\end{array}$ \\
\hline Rumen $\mathrm{pH}$ & 5.85 & 5.92 & 5.78 & 5.74 & 0.11 & 0.63 & 0.91 & 0.28 \\
\hline \multicolumn{9}{|l|}{ VFA } \\
\hline Acetic acid (mM) & 74.1 & 75.8 & 78.9 & 74.5 & 0.40 & 0.46 & 0.74 & 0.65 \\
\hline Propionic acid (mM) & $33.8^{\mathrm{a}}$ & $36.7^{\mathrm{ab}}$ & $42.6^{\mathrm{b}}$ & $41.9^{\mathrm{ab}}$ & 0.31 & 0.56 & 0.71 & 0.03 \\
\hline Butyric acid (mM) & 9.3 & 9.5 & 10.2 & 8.4 & 0.07 & 0.18 & 0.27 & 0.88 \\
\hline Iso Butyric acid (mM) & 0.8 & 0.8 & 0.8 & 0.7 & 0.01 & 0.63 & 0.43 & 0.79 \\
\hline Valeric acid (mM) & $1.5^{\mathrm{a}}$ & $1.7^{\mathrm{ab}}$ & $2.5^{\mathrm{b}}$ & $2.3^{\mathrm{ab}}$ & 0.03 & 0.52 & 0.96 & 0.02 \\
\hline $\begin{array}{l}\text { Acetic acid : Propionic } \\
\text { acid ratio }\end{array}$ & $2.23^{\mathrm{a}}$ & $2.16^{\mathrm{ab}}$ & $1.93^{\mathrm{bc}}$ & $1.86^{\mathrm{c}}$ & 0.10 & 0.99 & 0.39 & $<0.01$ \\
\hline Total VFA (mM) & 119.3 & 124.5 & 135.0 & 128.5 & 1.09 & 0.43 & 0.60 & 0.75 \\
\hline $\begin{array}{l}\text { Lactic acid (mg/100 } \\
\mathrm{mL})\end{array}$ & $2.75^{\mathrm{a}}$ & $2.50^{\mathrm{a}}$ & $5.80^{\mathrm{b}}$ & $4.32^{\mathrm{ab}}$ & 0.88 & 0.48 & 0.33 & 0.01 \\
\hline
\end{tabular}

\footnotetext{
${ }^{\mathrm{a}, \mathrm{b}}$ Means in the same row with different superscripts differ $(\mathrm{P}<0.05)$.

LCC - Low concentrate control; LCD - Low concentrate dosed; HCC - High concentrate control; HCD - High concentrate dosed.

s.e.m. - Standard error of the means.
}

Faecal score was not affected by the dosage of Me with the average faecal score for the control diet being 2.64 and for the treated group 2.58 (Table 4). The ideal faecal score for a high producing cow on a high concentrate diet is between 2 and 3 (Hall, 1999) which is in the same order as our results. The high concentrate diet clearly did not disrupt rumen fermentation to such an extent that SARA developed and faeces become runny and soppy, which is typical of acidosis.

There was a difference $(\mathrm{P}=0.016)$ in faecal $\mathrm{pH}$; being 6.62 and 6.43 respectively for the dosed and control cows. This suggests that less starch may have been hydrolysed in the abomasums and small intestine of cows in the treated groups, possibly due to more starch being fermented in the rumen and small intestine (Kreikermeier et al., 1991; Erasmus, 1997). This is supported by the fact that the faecal starch content of the dosed cows was lower $(\mathrm{P}=0.055)$ than the control cows, the values being 3.12 and $4.16 \%$ respectively. Aikman et al. (2008), however, did not observe any difference in faecal $\mathrm{pH}$ and faecal starch content when $M e$-treated cows were compared to control cows. 
Theurer (1986) demonstrated that changes in ruminal starch digestion may affect the amount of starch that flows to the small intestine. All this starch may not always be digested in the small intestine and it is possible with high starch diets that decreased starch digestion in the rumen may ultimately be reflected in increased faecal starch (Dunlop, 1972; Theurer, 1986). It is postulated that the reduced faecal starch content observed for dosed cows in this study indicated some improvement in starch digestion in the digestive tract, therefore suggesting a more favourable digestive tract environment.

Table 4 The effect of dosing live Megasphaera elsdenii NCIMB 41125 on faecal pH, faecal score and percentage starch in the faeces of high producing, early lactation, Holstein cows

\begin{tabular}{|c|c|c|c|c|c|c|c|c|}
\hline & \multicolumn{6}{|c|}{ Treatments } & \multicolumn{2}{|c|}{ Main Effects } \\
\hline & $\mathrm{LCC}$ & LCD & $\mathrm{HCC}$ & $\mathrm{HCD}$ & s.e.m. & $\mathrm{P}=$ & $\begin{array}{c}\text { Control / } \\
\text { Dosed } \\
\mathrm{P}=\end{array}$ & $\begin{array}{c}\text { Low / High } \\
\text { conc. } \\
\mathrm{P}=\end{array}$ \\
\hline Faecal pH & $6.47^{\mathrm{a}}$ & $6.72^{\mathrm{b}}$ & $6.39^{\mathrm{a}}$ & $6.53^{\mathrm{ab}}$ & 0.08 & 0.49 & 0.02 & 0.09 \\
\hline Faecal score (1 - 5) & 2.63 & 2.46 & 2.66 & 2.70 & 0.09 & 0.24 & 0.50 & 0.16 \\
\hline Faecal starch (\%DM) & $3.98^{\mathrm{a}}$ & $2.43^{\mathrm{b}}$ & $4.34^{\mathrm{a}}$ & $3.81^{\mathrm{ab}}$ & 0.53 & 0.35 & 0.06 & 0.11 \\
\hline
\end{tabular}

${ }^{\mathrm{a}, \mathrm{b}}$ Means in the same row with different superscripts differ $(\mathrm{P} \leq 0.05)$.

LCC - Low concentrate control; LCD - Low concentrate dosed; HCC - High concentrate control;

HCD - High concentrate dosed.

s.e.m. - Standard error of the mean.

The health status of cows was monitored on a regular basis. When the DMI and/or milk production declined more than $30 \%$ or more of the previous week's DMI and/or milk production for five consecutive days or more, due to any type of illness, the cow was culled from the trial. There were four and seven cows culled from the LCC and HCC group, respectively; which is more compared to the LCD and HCD groups where just one cow was culled per group. All the culled cows were replaced, thus 15 cows per treatment completed the trial. A 50\% reduction in health problems was observed when Me-treated cows were compared to the control cow group (Hagg \& Henning, 2007).

It could therefore be speculated, based on the health results, that with Me dosing, the percentage of concentrates in the diet could potentially be increased without the negative effect of a decreased DMI and/or milk production for periods of five days or more. A significant decrease in DMI and/or milk production could indicate on severe health problems, as has been discussed in Material and Methods. This could indicate that dosage of Me could have a positive effect on the health of the rumen as well as the whole animal.

\section{Conclusion and Recommendations}

Results indicate no clear advantage of dosing cows with $M e$, for neither the 60 or $70 \%$ concentrate diets. Primary production parameters such as milk production and feed efficiency, as well as rumen parameters (VFA, $\mathrm{pH}$, and lactic acid), were not affected by dosing. However, faecal starch was lower and faecal $\mathrm{pH}$ higher in dosed cows, and it could therefore be speculated that Me might have had a positive effect on the rumen environment. Furthermore only two cows were culled from the dosed groups, suggesting a positive influence of $\mathrm{Me}$ on the general health of stressed, early lactation cows. Further research is needed to better quantify the potential role of Me in preventing SARA, for example to see what the effect would be on production parameters if the frequency of dosing $M e$ is increased or if $M e$ could be freeze dried and supplemented to the cows in their feed. Further research is also needed to determine the effect of $M e$ on the general health of cows. 


\section{Acknowledgements}

We thank A. van Zyl and the farm support staff at the University of Pretoria Experimental farm, Hatfield, Pretoria for technical assistance and H.T. Groeneveld and M.F. Smith for statistical advice.

\section{References}

Aikman, P.C., Henning, P.H., Jones, A.K., Potteron, S., Siviter, J., Carter, S., Hill, S., Kirton, P. \& Szoka, R., 2008. Effect of administration of Megasphaera elsdenii NCIMB 41125 lactate utilising bacteria in early lactation on the production, health and rumen environment of highly productive dairy cows fed a high concentrate diet. KK Animal Nutrition Internal Report.

A.O.A.C., 2000. Official methods of analysis $\left(17^{\text {th }}\right.$ ed.). Association of Official Analytical Chemists, Inc., Arlington, VA, USA.

Apajalathi, J., Henning, P.H., Horn, C.H., Avaja, S. \& Kettunen, A., 2008. Capability of Megasphaera elsdenii NCIMB 41125 and other probiotics to prevent accumulation of lactic acid in a rumen model. KK Animal Nutrition Internal Report.

Beauchemin, K.A., Farr, B.I., Rode, L.M. \& Schaalje, G.B., 1994. Optimal neutral detergent fiber concentration of barley-based diets for lactating dairy cows. J. Dairy Sci. 77, 1013-1029.

Britton. R.A. \& Stock, R.A., 1987. Acidosis, rate of starch digestion and intake. In: Symposium Proceedings: Feed Intake by Beef Cattle. Ed. Owens, F.N., Publ. MP 121. Oklahoma State Univ., Stillwater, USA. p. 125.

Broderick, G.A., 2003. Effects of varying dietary protein and energy levels on the production of lactating dairy cows. J. Dairy Sci. 86, 1370-1381.

Callaway, T.R. \& Martin, S.A., 1997. Effects of cellobiose and monensin on in vitro fermentation of organic acids by mixed ruminal bacteria. J. Dairy Sci. 80, 1126-1135.

Castellano Giron, H. 1973. Comparison between dry ashing and wet digestion in the preparation of plant material for atomic absorption analysis. Atomic Absorption Newslet. 12, 28.

CPM-Dairy Beta version 3.0.5. Copyright 2006. By the Centre for Animal Health and Productivity, School of Veterinary Medicine, University of Pennsylvania, Kennett square PA; the Department of Animal Science, Cornell University, Ithaca NY; and the William H. Miner Agricultural Research Institute, Chazy, N.Y., USA.

De Vries, T.J., Dohme, F. \& Beauchemin, K.A., 2008. Repeated ruminal acidosis challenges in lactating dairy cows at high and low risk for developing acidosis: Feed sorting. J. Dairy Sci. 91, 3958-3967.

Dunlop, R.H., 1972. Pathogenesis of ruminant lactic acidosis. Adv. Vet. Sci. Comp. Med. 16, 259-302.

Erasmus, L.J., 1997. Proposed commercialization of CH4 cultures as an antidote against ruminal acidosis in high producing dairy cows. ADSRI. Progress report, ADSRI, Private Bag x2, Irene 0062, South Africa.

Erasmus, L.J., Robinson, P.H., Ahmadi, A., Hinders, R. \& Garrett, J.E., 2005. Influence of prepartum and postpartum supplementation of a yeast culture and monensin, or both, on ruminal fermentation and performance of multiparous dairy cows. Anim. Feed Sci. Technol. 122, 219-239.

Gallo, L., Carnier, P., Cassandro, M., Mantovani, R., Bailoni, L., Contiero, B. \& Bittante, G., 1996. Change in body condition score of Holstein cows as affected by parity and mature equivalent milk yield. J. Dairy Sci. 79, 1009-1015.

Gibbs, B.F., Itiaba, K., Crawhall, J.C., Cooper, B.A. \& Mamer, O.A., 1973. A rapid gas chromatographic method for the quantitation of volatile fatty acids in urine. Propionic acid excretion in vitamin B12 deficiency.

http://www.ncbi.nlm.nih.gov/entrez/query.fcgi?cmd=Retrieve\&db=PubMed\&list_uids=4725416\&dop $\mathrm{t}=$ Abstract

Goering, H.K. \& Van Soest, P.J., 1988. Forage Fiber Analyses. Agricultural Handbook No 379, A.R.S., U.S. Dept. Agric. ADSRI - Jan 1988.

Hall, M.B., 1999. Management strategies against ruminal acidosis. $10^{\text {th }}$ Annual Florida Ruminant Nutrition Symposium, Gainesville, FL. pp. 104-113.

Hagg, F.M. \& Henning, P.H., 2007. Evaluation of supplementation with Megasphaera elsdenii NCIMB 41125, a lactate utilizing rumen microorganism, on performance in Holstein dairy cows. KK Animal Nutrition Internal Report. 
Henning, P.H., 2004. Acidosis in high-producing ruminants - myth or menace? AFMA Matrix vol. 13 nr. 1. pp. 38-41.

Hibbert, B., Robinson, J.A., Greening, R.C., Smolenski, W.J., Bell, R.L. \& Peters, J.P., 1993. The effect of route of administration of isolate 407A (UC-12497) on feed intake and selected ruminal variables of beef steers in an acute acidosis inappetance model. Proc. $22^{\text {nd }}$ Biennial Conference on Rumen Function, Chicago, IL. p. 19 (Abstr.).

Hutjens, M.F., 2002. Rumen acidosis. Take home messages. http:/www.aces.uiuc.edu/ ansystem/dairyrep96/acidosis.html

Johnson-Van Wieringen, L.M., Harrison, J.H., Davidson, D., Swift, M.L., Von Keyserlingk, M.A.G., Vazquez-Anon, M., Wright, D. \& Chalupa, W., 2007. Effects of rumen-undegradable protein source and supplemental 2-hydroxy-4-(methylthio)-butanoic acid and lysine-NCL on lactation performance in dairy cows. J. Dairy Sci. 90, 5176-5188.

Jonker, J.S., Kohn, R.A. \& Erdman, R.A., 1998. Using milk urea nitrogen to predict nitrogen excretion and utilization efficiency in lactating dairy cows. J. Dairy Sci. 70, 1563-1571.

Kennelly, J.J. \& Khorasani, G.R., 2001. Influence of carbohydrate source and buffer on rumen fermentation characteristics, milk yield, and milk composition in lactating Holstein cows. J. Dairy Sci. 84, 1707-1716.

Kennelly, J.J., Dalton, D.L. \& Ha, J.K., 1988. Digestion and utilization of high moisture barley by lactating dairy cows. J. Dairy Sci. 71, 1259-1266.

Keunen, J.E., Plaizer, J.C., Kyriazakis, L., Duffield, T.F., Widowski, T.M., Lindinger, M.I. \& McBride, B.W., 2002. Effects of a subacute ruminal acidosis model on the diet selection of dairy cows. J. Dairy Sci. 85, 3304-3313.

Krause, K.M. \& Combs, D.K., 2003. Effects of forage particle size, forage source, and grain fermentability on performance and ruminal pH in midlactation cows. J. Dairy Sci. 86, 1382-1397.

Krause, K.M., Combs, D.K. \& Beauchemin, K.A., 2002. Effects of particle size and grain fermentability in midlactation cows.1. Milk production and diet digestibility. J. Dairy Sci. 85, 1936-1946.

Kreikermeier, K.K., Harmon, D.L., Brandt, R.T., Avery, T.B. \& Johnson, D.E., 1991. Small intestine starch digestion in steers: Effect of various levels of abomasal glucose, corn starch, and corn dextrin infusion on small intestinal disappearance and net glucose absorption. J. Anim. Sci. 69, 328-338.

Kung, L., Hession, J.R. \& Hession, A.O., 1995. Preventing in vitro lactate accumulation in ruminal fermentations by inoculation with Megasphaera elsdenii. J. Anim. Sci. 73, 250-256.

Linn, J, Raeth-knight, M., Fredin, S. \& Bach, A., 2006. The challenge of measuring feed efficiency in lactating dairy cows. Proc. 2006 Cornell Nutrition Conference, NY. USA.

MacRae, J.C. \& Armstrong, D.G., 1968. Enzyme method for determination of alpha-linked glucose polymers in biological materials. J. Food Sci. Agric. 19, 578-581.

Maekawa, M., Beauchemin, K.A. \& Christensen, D.A., 2002. Effect of concentrate level and feeding management on chewing activities, saliva production, and ruminal $\mathrm{pH}$ of lactating dairy cows. J. Dairy Sci. 85, 1165-1175.

Marounek, M., Fliegrova, K. \& Bartos, S., 1989. Metabolism and some characteristics of ruminal strains of Megasphaera elsdenii. Appl. Environ. Microbiol. 55, 1570-1573.

Mutsvangwa, T., Walton, J.P., Plaizier, J.C., Duffield, T.F., Bagg, R., Dick, P., Vessie, G. \& McBride, B.W., 2002. Effects of monensin controlled-released or premix on attenuation of subacute ruminal acidosis in dairy cows. J. Dairy Sci. 85, 3454-3461.

Nocek, J.E., 1997. Bovine acidosis: Implications on laminitis. J. Dairy Sci. 80, 1005-1028.

Nordlund, K.V. \& Garrett, E.F., 1994. Rumenocentesis: A technique for the diagnosis of herd-based subacute rumen acidosis. Bovine Pract. 28, 109-112.

NRC, 2001. Nutrient Requirements of Dairy Cattle ( $7^{\text {th }}$ ed.). National Academy Press, Washington, D.C., USA.

Oetzel, G.R., Nordland, K.V. \& Garrett, E.F., 1999. Effect of ruminal pH and stage of lactation on ruminal lactate concentrations in dairy cows. J. Dairy Sci. (Suppl.) 82, 38 (Abstr.).

Owens, F.N., Secrist, D.S., Hill, W.J. \& Gill, D.R., 1998. Acidosis in cattle: a review. J. Anim. Sci. 76, 275-286.

Pryce, J.D., 1969. A modification of the Barker-Summerson method for the determination of lactic acid. Analyst 94, 1151-1152. 
Robinson, J.A., Smolenski, W.J., Greening, R.C., Ogilvie, M.L., Bell, R.L., Barsuhn, K. \& Peters, J.P., 1992. Prevention of acute acidosis and enhancement of feed intake in the bovine by Megasphaera elsdenii 407A. J. Anim. Sci. 70 (Suppl. 1), 310 (Abstr.).

Samuels, M.L., 1989. Statistics for the Life Sciences. Collier MacMillan Publishers, London.

SAS, 2001. Statistical Analysis Systems user's guide ( $8^{\text {th }}$ ed.). SAS Institute Inc., Cary, N.C., USA.

Slyter, L.L., Tung, R.S. \& Kung Jr., L., 1992. Effect of monensin and lysocellin on growth and fermentation by pure cultures of ruminal bacteria. J. Appl. Anim. Res. 1, 1.

Sutton, J.D., Dhanoa, M.S., Morant, S.V., France, J., Napper, D.J. \& Schuller, E., 2003. Rates of production of acetate, propionate and butyrate in the rumen of lactating dairy cows given normal and lowroughage diets. J. Dairy Sci. 86, 3620-3633.

Tamminga, S., 2001. Effect of feed, feed composition and feed strategy on fat content and fatty acid composition in milk. Bulletin of the International Dairy Federation. 366/2001. pp. 15-27.

Theurer, C.B., 1986. Grain processing effects on starch utilization by ruminants. J. Anim. Sci. 63, $1649-1662$.

Van der Merwe, F.J. \& Smith, W.A., 1991. Typical nutrient composition of Southern African feedstuffs. In: Animal Nutrition. Anim. Sci. (Pty) Ltd., Pinelands, South Africa. p. 204.

Van Soest, P.J. \& Robertson, J.B., 1981. The Analysis of Dietary Fibre in Food. Eds James, W.P.T. \& Theander, O., Dekker, New York, ADSRI - Jan 1988.

Wildman, E.E., Jones, G.M., Wakner, P.E., Bowman, R.L., Troutt, H.F. \& Lesch, T.N., 1982. A Dairy cow body condition scoring system and its relationship to selected production characteristics. J. Dairy Sci. $65,495-501$. 